\title{
The chasm between James VI and I's vision of the orderly "Middle Shires" and the "wickit" Scottish Borderers between 1587 and 1625
}

\author{
ANNA GROUNDWATER \\ Scottish History, University of Edinburgh
}

L'élimination du crime le long des frontières anglaises, de pair avec un plus grand sérieux face à ce problème à partir de 1587, fait partie d'une monopolisation générale de l'utilisation de la violence et des procédés légaux par le gouvernementécossais. Au fur et à mesure que la succession de Jacques Stuart sur le trône anglais devenait vraisemblable, le contrôle des frontières s'est accéléré, et les chefs expéditionnaires des raids outre frontières y ont contribué. Aux environs de 1607, Jacques affirmait que les désordres frontaliers s'étaient transformés en une harmonie exemplaire au sein d'une nouvelle unité transfrontalière, les « Middle Shires ». Toutefois, ceci était davantage l'expression de la vision qu'avait Jacques de l'union politique de l'Écosse et de l'Angleterre, contredite par la séparation effective des organisations frontalières écossaise et anglaise, et qui a duré jusqu'en 1624. Cet article examine les transformations de la loi et du crime dans les régions frontalières, ainsi que la détérioration de la perception qu'avait le gouvernement de ces frontières.

\begin{abstract}
Those confining places which were the Borders of the two Kingdomes, where heretofore much blood was shed, and many of your ancestours lost their lives; yea, that lay waste and desolate, and were habitations but for runnagates, are now become the Navell or Umbilick of both Kingdomes [...] where there was nothing before $[\ldots]$ but bloodshed, oppressions, complaints and outcries, they now live every man peaceably under his owne figgetree [...] The Marches beyond and on this side Twede, are as fruitfull and as peaceable as most parts of England. ${ }^{1}$
\end{abstract}

Co James declared in March 1607 to the English parliament as its members dis$\checkmark$ cussed the merits of union. Three hundred years of Anglo-Scottish hostilities in the Borders, sometimes latent, often overt, were over; it was to be supposed that harmony had replaced enmity. Two important strands of James VI and I's thinking stand out in his speech: the benefits to both England and Scotland of union as a result of his succession to the throne of England in 1603, and the suppression of crime that had been achieved within a region previously perceived to have been beyond the control of either crown. With hindsight, it becomes clear that both statements 
are misrepresentative, more expressive of James's own hopes for peace at the heart of a newly unified Great Britain than the actual situation in the Borders, in 1607, gave grounds for believing was achievable. They were also misrepresentative of the situation before the regnal union.

James frequently deployed the body as an allegory for a new Britain which, after 1603, was embodied in his person. In 1604 he told the Upper House of the English Parliament of "the benefits that do arise of that Union which is made in my blood [...] [with me] as the head wherein that great Body is united."2 Everything was to be done to secure the untroubled circulation of that blood; anything that blocked it was to be removed. Thus in April 1603 the Borders, which were by "the happy union [...] the very heart of the country" were renamed the "Middle Shires." 3 They were to be the same as the rest of Britain, "the middlest of the Isle, and so as easily ruled as any part thereof." 4 Any laws differentiating the Borders from the rest of Britain were to be abolished, and any local crime that upset the smooth flowing of the kingdom's blood was to be suppressed. The Borders were to be as peaceful as the rest of Britain. To take the allegory one step further, relations between the people on either side of the border, once hostile and uneven, were now to exemplify the regularly beating heart of the new multiple kingdom.

To ensure the successful suppression of crime in the Borders, a pacification of the cross-border region was initiated in 1603 and formalized in the creation of the Commissions of the Middle Shires in 1605.5 Though the consistency of method was novel, James's interest in the enforcement of order in the Borders predated 1603 . Throughout the sixteenth century, successive monarchs and regents had occasionally prioritized the suppression of "disorder" in the Borders, making sporadic judicial raids into the region. These efforts were not, however, sustained. Indeed, it often seemed that disorder, where it affected relations with England, was being positively encouraged. However, in 1587, a fore-runner of James's eventual attitude towards the region could be found in an act which for the first time equated the people of the Borders with the barbaric and "disorderit" highlanders. ${ }^{6}$ The act illustrated the growing perception of the borderers as especially troublesome. Despite this initial interest, the subsequent series of judicial raids into the Borders was not maintained: by the mid 1590 it appeared that James was happy to tolerate disorder there as a leverage in his attempts to be formally recognized as Elizabeth's heir. In 1597, however, James's policy began to change as he grew increasingly alarmed over Elizabeth's reluctance to confirm his succession. ${ }^{7}$ In addition, through much of 1596 and throughout 1597, Elizabeth withheld the annual pension that she had granted to James, and on which he had grown increasingly dependent, in order to force him to take action 
in the Borders. ${ }^{8}$ As a result, the two most notorious of James's officers in the region, Walter Scott of Buccleuch, the keeper of Liddesdale, and Robert Ker of Cessford, the warden of the Middle March, were forced eventually to surrender themselves into English custody. ${ }^{9}$ On their release they were to become two of the principal agents of the new order, both through their authority over their own kindreds and alliances, and as the king's officers amongst the rest of the borderers.

However, though James's aspirations for an orderly crime-free Britain found ready expression in the example of the Borders, the smooth circulation of the kingdom's blood was to be facilitated throughout Britain, in the rest of Scotland as much as in the Borders. Crime was to be suppressed wherever it occurred. This was not a process that had started at regnal union in 1603: ${ }^{10}$ James's policies on crime had been detectable long before then. The most striking evidence of this was his personal interest in the suppression of feuding, evident in the 1580 s, increasing throughout the 1590s, and codified in the "Act anent Feuding" of 1598. This process was part of a wider harnessing of the judicial processes within the hands of the state with the king at its head. And the personal nature of his intervention in the resolution of individual feuds exemplified James's identification of himself with the body of the state.

The very fact that James was addressing crime, particularly violent crime, throughout Scotland before union indicates that it was taking place throughout the kingdom too: crime was not a Borders-specific phenomenon and nor was feuding. The steadily worsening perception of the borderers, however, meant that any crime that did occur in the Borders was viewed with increasing alarm and condemnation by James and the privy council. And when this disorder was seen to threaten both James's succession to the English crown and, after 1603, the peaceful heart of the united kingdoms, crime in the Borders took on an extra significance and attracted even greater opprobrium.

In consequence, a number of issues and themes arise out of these contexts: evidence of the effect of the succession to the English throne on government action in the Borders; a deteriorating perception of the borderers; increasingly persistent attempts to deal with the perceived disorder in the Borders prior to regnal Union and James's insistence on order there, after 1603, to facilitate a full political Union; James's own vision of the Middle Shires as an exemplar of the benefits of a unified Great Britain; and, most significantly, James's own involvement in attempts to focus judicial processes and the exercise of violence within the control of the state.

It has been suggested that the crown's reining in of the legitimate use of violence was part of a broader process of evolution in the powers of the state and as such 
can be discerned as one of the dynamics in the formation of the state. A discussion here of the nature of the early modern state is beyond the scope of this essay and deserves the closer attention that others, such as Julian Goodare, have been able to give it. However, it is important to note that the state should be assessed not merely by its institutions, but also by the interactions of those participating within it: and, as Keith Brown has observed, James was able to increase the power of the Scottish state by utilizing the consent of its leading members, rather than forcibly coercing them. ${ }^{11}$ The long-term nature of these developments, however, should be emphasized: James's accumulation of control over judicial systems, by 1625 , was no more complete than the formation of the state. ${ }^{12}$

The processes at work in the Borders were part of a more general expansion in the functions, authority and institutions of the state. What was happening in the Borders, while intensified by concerns over the succession, was happening elsewhere throughout Scotland. An analysis of the crown's policy towards crime in the Borders, before and after union, will illuminate James's policies on crime within the wider kingdom of Scotland. In order to see how these developed, a comparison is made of policies towards crime throughout Scotland in 1587 and how they had evolved by 1625 . A similar comparison will be made of the processes at work in the Borders leading up to 1603 and what was there in 1625 . Finally, what was actually happening in the Borders will be distinguished from central government's perception of the situation there at any given time. James wanted "order" in his new Middle Shires: there may have been less crime by 1625 , but was it the "order" that James had envisaged?

In the latter half of the sixteenth century, the administration of justice in the Scottish Borders was part of a judicial system that existed elsewhere in the kingdom. The day-to-day judicial administration of the Borders lay in the hands of the hereditary sheriffs of each shire, who held regular, usually weekly courts, and the landholders with private jurisdiction, as it was in the Lowlands. ${ }^{13}$ However, as a result of the region's geographical location on the border with a hostile England, an additional framework of judicial authority had been superimposed. For this purpose, the Borders were divided into three areas known as the East, Middle, and West Marches - each of which was the responsibility of a crown-appointed warden whose duties were primarily to negotiate the redress of cross-border crime with their counterparts on the other side of the border. These officials were usually members of prominent local families and the wardenship tended to stay in within the same family, the Kers in the Middle March and the Homes in the East, though in the West it alternated between the Johnstones and the Maxwells. ${ }^{14}$ The lordship of Liddesdale, a valley on the border and technically within the Middle March, was 
under the jurisdiction of a keeper: the crown-appointed keeper was often the owner of the lordship (the earls of Bothwell until their forfeiture in 1594), occasionally the Middle March warden, and at other times an outsider. The wardens and the keepers usually maintained relatively regular days of truce where they met their opposites and settled individual complaints: this pattern, however, could be interrupted by fluctuating Anglo-Scottish relations, as they were in the early 1580 s. What is significant, however, is that for all the English complaints about Scottish raids, and lack of redress, and alarmist castigation of the "wicked" borderers by the Scottish privy council, a recognized and fully functioning judicial system existed in the Borders, which the government could use if it chose to do so.

In 1587, James, with the assistance of his chancellor John Maitland of Thirlestane, was beginning to make a personal mark on the government of Scotland. It was nearly two years on from the overthrow of the earl of Arran, the last of the regentesque figures that had dominated Scottish government since James's infancy. James and Maitland were consciously pursuing a policy which sought to assert the crown's authority over many aspects of life, including the church and the execution of justice. In July 1587 a parliament was held in Edinburgh which passed an extraordinary number of acts, 136 in all, in what Julian Goodare has termed an "absolutist manifesto." 15 Relating particularly to the Borders was the act "for the quieting and keeping in obedience of the disorderit subjectis inhabitantis of the bordouris hielandis and ilis." 16 The leaders of the kindreds and landlords in these periphery regions were to be held accountable for the good behaviour of their dependants. As one measure in 136 , however, this act should be viewed as part of the broader development of crown authority. Any competing authorities in Scotland, such as that of the kirk or the landed elite, were being strongly encouraged to allow the crown to harness their powers. In particular, James wanted to control the judicial system: he wrote, "Justice, which is the greatest virtue [...] properly belongeth to a kings office." 17

This process intensified through the late 1580 os and on throughout the 1590 . The privy council issued various ordinances to tighten up those actions which were perceived to be abuses of or deleterious to justice; such measures were intended to facilitate the imposition of crown authority and "order" throughout Scotland. For instance, in 1590 all commissions of justiciary and lieutenancy were annulled since they had often been purchased not to enable "the setting fordwart of justice" but for the purchasers' "awne particulair proffeit and using of revengement upon personis aganis quhome thai professit evill will and inimitie." This ordinance was repeated in 1594 suggesting that the first order was not fully implemented. ${ }^{18}$ A privy council ordinance of 1594 called for the holding of justice courts "becaus of the grit 
disordor ower all the pairtes of the realme": though it particularly mentioned the Borders, proclamations of justice courts were to be made at Stirling, Aberdeen, and Inverness. ${ }^{19}$ Further measures were taken against sheriffs who were failing in their duty: though the Borders sheriffs were called to account for their activities, there was a general summons, in 1600 , for all sheriffs to attend a commission to consider how to make them more effective. In 1601, a proclamation for the "administration of better justice" warned that James was to appear himself at courts in Lothian, Fife, and Angus. ${ }^{20}$ Changes were not limited to the judicial system, since efforts were being made to prevent violent crime occurring in the first place: between 1593 and 1597 seven proclamations were made against the wearing of hagbutts and pistols. These were succeeded by two similar acts in 1598 and 1600, all of which were targeted at the whole kingdom and not just the "wicked" men of the Borders. ${ }^{21}$

Of all the measures taken by James to harness judicial processes within the crown's remit, none exemplified more clearly his determination to assert his authority than his personal interest in the suppression of feuding. Over recent years, the traditionally negative view of feuding has been reassessed by Jenny Wormald and Keith Brown. Both have shown how feud, though violent, provided the framework for its own resolution. Wormald goes further, calling this framework a "force for peace." ${ }^{22}$ However, resolution was in the hands of the participants, while the crown only sporadically intervened. James had come to disparage this private method of resolution which had often resulted in only a temporary peace. "Thinking on his own estate and the estate of the commounweill, altogether disordoured and shaken loose by reason of the deadly feuds and controversies standing among his Highness's subjects," James had decided "to purge this land of the proud contempt" these feuds represented to his authority. ${ }^{23}$ Brown links this to a process whereby the state, as embodied by James, was gradually moving towards a monopoly on the use of violence. ${ }^{24}$ In May 1587, James, attempting to reconcile his feuding nobility, invited them to a banquet at Holyrood at which they were made to shake hands and then progress through Edinburgh in apparent harmony. Similarly unrealistic was the "Act for Universal Concord Among the King's Lieges" passed by parliament in July. ${ }^{25}$

Throughout the 1590 s there was a crescendo of ordinances relating to feuding. At least ten such ordinances were made from 1595 to $1597 .{ }^{26}$ These began with an ordinance in late 1595 in which James was resolved to "have all the said feuds removed and taken up a perfect reconciliation and agreement" among his subjects "to the advancement of his Majesty's authority and service."27 The combatants in thirteen named feuds were summoned before the King and council "to underlie such 
order as shall be prescribed for removing the said feuds"; any disobedience was to be "pursued with fire and sword." James was described as being "chiefly occupied in this errand" (ie against feuding), and in 1596 several further ordinances related to the violation of the 1595 edict. ${ }^{28}$ These proclamations culminated, in 1598 , in an act agreed by a Convention of the Estates for the "removing and extinguishing of deadly feuds," charging all participants to submit their disputes to arbitration by the king and council. James's continuing prioritization of the suppression of feuding was underlined by the Parliament's ratification in 1600 of the act of $1598 .{ }^{29}$

Despite all of these measures being directed at the whole kingdom, feuding has been traditionally seen as a Borders and Highlands phenomenon. ${ }^{30}$ In 1596 , English reports noted the prevalence of "deadly feud, the word of enmity in the Borders, implacable without the blood [kin] and whole family distroyed." They complained that the Scottish wardens themselves were "extraordinarily addicted to partialities, favour of their blood, tenants and followers." ${ }^{31}$ English opprobrium, however, ignored the involvement of many English borderers in feuding: Sir John Forster, the English Middle March warden, was himself, with the Widdrington family, at feud with Lord Eure. ${ }^{32}$ There is no doubt that many borderers were at feud. In 1589, before a court could be held at Peebles, the privy councilors asked for the barons and lairds attending to subscribe assurances to keep the peace. This request was answered tartly that those who "were under feud had already subscribed particular assurances which were sufficient and the subscription of any further assurances was unnecessary." 33 In 1599, the privy council noted that "the chief and only cause of the great misrule and unquietness of the West Border [...] has been the deadly feuds and quarrels standing between the principal noblemen and barons [there] and seeing the said Border cannot be quieted and settled [...] unless the said feuds be removed"; the council ordered the kindred leaders in the West March to submit their feuds to the council for resolution. ${ }^{34}$ This particularly referred to the unrelenting feud between the Maxwells and the Johnstones, a dispute which had festered throughout the sixteenth century, occasioning a large scale battle between the two surnames and their allies at Dryfe Sands in 1593. It was still being felt in the 1620 s, when an exemption was granted to the Johnstones from the commissioner Robert Maxwell earl of Nithsdale's jurisdiction. ${ }^{35}$ In the Middle March a similarly long-lasting feud between the Kers of Cessford and the Scotts of Buccleuch had its final flourish when, in 1596, Cessford challenged Buccleuch to a duel..$^{36}$ Cessford seemed particularly given to feuding: he had been involved in the killing of his kinsman William Ker of Ancrum in 1591, as part of his ongoing feud with his other cousin Andrew Ker of Ferniehirst. ${ }^{37}$ In 1602 James personally intervened, ordering 
the two to subscribe a mutual assurance. Though Ferniehirst and Cessford settled their differences, hostility remained between their dependants, a fracas taking place as late as $1619.3^{3}$ There is certainly enough evidence of prevalent feuding in the Borders to prejudice any perception of borderers, both among contemporaries and historiographically.

However, as Keith Brown has indicated, and as conclusively demonstrated elsewhere, feuding was not particular to the Borders. ${ }^{39}$ Of the 34 nobles and lairds listed at feud in 1595, only four were from the Borders. In the period 1604 to 1610 , 1,965 acts of caution were registered in Scotland and predominantly related to feud. Around 330 were for the Borders (that is, about seventeen per cent of the total); of these, around a third originated in the Middle March, very many fewer in the East March, and around a half from the West March. ${ }^{40}$ These figures for the Borders broadly concur with Brown's findings that feuds in the Borders numbered around 23 per cent of the national total, compared with a figure of 40 per cent for the Lowlands south of the Tay. If population figures for the Borders are quantified at around ten per cent, this means that record of crime in the Borders was twice the national per capita rate. However, several historians, including Keith Brown, have emphasized the difficulties in amassing representative figures for the incidence of feud. ${ }^{41}$ Record of it would often only occur when a case appeared before the council, and since most feuds were settled privately, many did not reach the council's notice. This was probably even more true of feuds taking place further away from Edinburgh; the relative proximity of the Borders to Edinburgh meant it was easier to summon participants and thus to create a record of the incident. Similarly, English records of feuding in the Borders should not be given a disproportionate significance, since their reports were generally limited to discussion of the Borders, ignoring feuding elsewhere. Feuding appears to have been more prevalent in the Borders, but it was not far outstripping the figures for other regions. Feud was part of life throughout Scotland.

When measures were taken to suppress feuding, they were undertaken with the whole of Scotland in mind: ordinances were as applicable to Fife as they were to the Borders. However, it was one thing to make an ordinance; it was another to persuade the landed elite, who habitually had used the feud to pursue disputes, to forsake the practice of generations. Why should they feel that it was better to submit their quarrels to official arbitration, when they had held the unofficial authority to settle their own disputes or those of their dependants? James could, in theory, coerce them to uphold any official settlement. However, so widespread was feuding that it would have been difficult for James to enforce every arbitration. Moreover, the 
legislation of the 159 os appeared to have a significant impact in a relatively short time: by the 1620 s, the numbers of cases appearing before the council had dramatically declined. ${ }^{42}$ Such a rapid transformation suggests that the nobility and lairds, whom the legislation mostly affected, were not resisting what amounted to a challenge to their authority to conduct or settle disputes in their own localities. Indeed it suggests that they were co-operating with the crown. Keith Brown notes that the increasing levels of feuding in the politically unstable years of James's minority in the $1570 \mathrm{~s}$ and early $1580 \mathrm{os}$, meant that the nobility was disposed towards a containment of this violence by the 1590 s. In addition, the ideological effect of the protestant reformation encouraged the nobility "to set themselves against private violence." 43

However, it was not merely the nobility that was co-operating with James, but also the lairds - and this was as true of the Borders as it was of the Lowlands. This was especially significant in the Borders, where there were few resident nobles, but a large number of greater, or more powerful, lairds. ${ }^{44}$ As leaders of their kindreds, they exercised an immediate authority over their kinship groups and allies in their localities. For instance, in 1528 Walter Scott of Buccleuch was named as an "overman" in the private arbitration of a feud between two Scotts of Borthwick, a subsidiary branch of the Scott kindred or surname. All participants agreed to abide by his judgement. ${ }^{45}$ In 1585 , a subsequent Buccleuch agreed with another Scott, of Allanhaugh, to resolve a feud between them, taking burden for their kin and friends' future behaviour. Allanhaugh promised to "serve, maintain and defend my said chief," while Buccleuch promised to "fortify, maintain and defend" Allanhaugh and his kin "as a chief ought to do to his surname and friends." Similarly, in 1599 Buccleuch was the arbiter in a dispute between two of an allied surname, the Elliots of Redheugh..$^{6}$ Lairds such as Buccleuch might have been expected to resent the encroachment on their authority that the imposition of official arbitrations represented. Instead, James had achieved their co-operation. Some of the means he used were traditional: kindred leaders were made to assume responsibility for their dependants' behaviour through the exercise of a general band of assurance, and financial penalties were used for non-compliance. However, what was new was the way in which James adroitly managed to include the lairds within the structure of his evolving government. Most obviously this was through the lairds' admission to parliament in 1587.47

More significantly, however, was the way in which he rewarded those who cooperated, either by granting them office at court or in their locality, or by grants of land. In 1594, Buccleuch, only recently forgiven for his involvement with the errant earl of Bothwell, ${ }^{48}$ was granted the lordship of Liddesdale and numerous others 
lands from Bothwell's forfeiture. Added to his already extensive landholdings in Selkirkshire and Roxburghshire, these grants hugely expanded his authority in the region. Moreover, James appointed him keeper of Liddesdale, which meant that Buccleuch had official authority to negotiate with the English as one of the king's representatives. ${ }^{49}$ Buccleuch's authority as the leader of the large Scott kindred, with the loyalty of such allies as the Murrays and the Elliots, meant that he could impose any ruling on behalf of the crown over a large number of people. An English report of 1596 noted that most of the men of Liddesdale were joined with Buccleuch "by oath and script." 50 In 1599 "the principillis of oure brenche" of several Elliot and Armstrong surnames subscribed bands to Buccleuch promising to relieve him for any of their offences, since Buccleuch "by virtue of the general band, has found caution and bound and obliged him that the whole inhabitants of the bounds of Liddesdale [...] shall be answerable to the King's Majesty and his laws." ${ }^{1}$ The same year, Buccleuch's properties were consolidated within a new charter for the barony of Branxholm. He occasionally attended privy council meetings. Seven years later, Buccleuch was ennobled in recognition of his service to the crown in the Borders, and was appointed a privy councillor, attending regularly until his death in 1611. In 1610, he was appointed a JP, as, subsequently, was his heir. ${ }^{52}$ The rescuer of Kinmont Willie from Carlisle castle in 1596,53 the man at feud with Cessford, the subject of repeated English complaint over his raiding activities and the non-fulfillment of his keepership duties, had become the enforcer of the crown's peace and a member of government.

By including Buccleuch within central government, James was able to harness Buccleuch's power in his locality, and to concentrate that authority within the hands of the crown. Simultaneously, the crown was able to extend its official remit within Buccleuch's locality and utilize the manpower that Buccleuch could provide in the Borders, while keeping Buccleuch and his allies happy and retaining their service both in Edinburgh and in the Borders. Any violence or settlement of dispute that Buccleuch subsequently perpetrated was, from the late $159 \mathrm{os}$, done in the name of the crown. In 1608 James recognized Buccleuch's efforts in an indemnity which called him a "man of energy, prompt in council and action, powerful in fortune, force, arms and following [...] in punishing malefactors and refractory and rebellious persons." 54 The same people may have been involved "on the ground," but their authority derived from the crown. They were acting as part of and on behalf of the state. The power to settle dispute, and the use of violence to resolve a feud, were increasingly being drawn within the control of the state. If the state can be seen as more than mere institutions, the links that those such as Buccleuch and his men 
provided between Edinburgh and the Borders were the sinews of government; their relations with each other and with the crown, the dynamics of the structure of the state. Feuding was not the only crime to concern James's government. There was a common apprehension that other forms of violent crime were especially prevalent in the Borders. The preambles to statutes repeatedly despaired of rampant crime. In 1596 Robert Birrel described the terror caused in Edinburgh by the "great rumour" that James would send in the borderers "as should spulzie [rob] the town." The fear inspired by the stereotypical borderer was implicit. ${ }^{55}$ Voicing the court's perception of the region, Sir Richard Maitland of Lethington (1496-1586) in a poem complained "Aganis the Theivis of Liddisdaill":

Off liddisdaill ye commoun thevis

Sa peirtlie stelis, now and revis

That nane can keip, hors nolt nor scheip

Nor yit dar sleip, for thair mischevis [...]

Thai have neir hand hirreit haill

Ettrik forrest and Lawderdaill

now ar thai gane, in lowthiane

And sparis nane, that thai will waill. ${ }^{56}$

This derogatory impression of the borderers has indelibly marked most subsequent histories of the region: even the most positive accounts of the region, such as the romances spun by Sir Walter Scott in the nineteenth century, dwell on the violent (though heroic) nature of the borderer.

What were the predominant types of crime in the Borders? As Maitland suggested, the borderers were notorious for large scale livestock raiding. But the picture was more complex than that: various judicial records including those of the privy council, high court of justiciary, court of session and local sheriff courts show the frequent occurrence of feuding, non-payment of debts, violent dispute over pasturage rights and territorial boundaries, and theft (usually on a small scale) of livestock: a horse or a couple of cows or sheep. ${ }^{57}$ It is almost impossible to quantify the real levels of any of these crimes-but cattle-raiding in the Borders has often been described as part of the local economy..$^{8}$ This conclusion, however, ignores the significance of the prevalence of other types of crime, such as feud-related crime, in the Borders, that more closely correlates the situation there to elsewhere in Scotland. Moreover, it does not give due acknowledgement to the fact that livestock was the only thing of value in the region to steal: theft in the Lowlands would necessarily be of the valuable goods that existed there, such as household "geir" or money and sometimes livestock. There is no denying that the borderers could be and were 
"wicked": however, the perception of the widespread nature of large scale raiding has marked the Borders out as completely dissimilar to the Lowlands.

If the figures for crime are analyzed dispassionately, a rather different picture emerges. Crime, difficult at most times to quantify, is notoriously difficult to assess in this period: many cases went unrecorded, often being dealt with privately or at a local level by sheriffs or bailie courts, whose records no longer exist. However, when all the entries in the register of the privy council from 1573 to 1599 which related to violent crime are enumerated, cases from the Borders accounted for just under 20 per cent of the national figures. ${ }^{59}$ There was a rapid expansion of the record of violence nationally from 1587; this was largely accounted for by the increasing numbers of assurances relating to feuds being subscribed as central government increasingly drew the resolution of dispute throughout Scotland within its remit. Michael Wasser's figures for 1603 to 1638 , for violent crime appearing before the privy council and the High Court of Justiciary, draw a similar conclusion of around 20 percent originating in the Borders. ${ }^{60}$ This, like the figures for feud above, was approximately twice the average per capita rate. However, crime in the Borders was almost certainly over-represented in these figures: the figures include a large number of assurances subscribed by borderers in Edinburgh, but hardly any such assurances were recorded from the west Highlands, and only a few from Inverness and Aberdeen. No one could suggest that feuding was not taking place in these more remote areas; record of it, however, was failing to make the registers in Edinburgh. In fact, the higher representation of borderers in central crime records reflected both the proximity of the region to Edinburgh and the heightened levels of government there as a result of its position on the Anglo-Scottish frontier. Both Wasser and Philip Dixon draw similar conclusions. ${ }^{61}$

There was violent crime in the Borders, but so was there throughout Scotland. As Wasser concludes, crime in Scotland was "serious, extensive, and frequently practiced by the landed elite." ${ }^{62}$ While the poet Maitland may have despaired of the criminal borderers, when he also wrote

\author{
In Scotland gritter miserie \\ grit ewill in to this land we se \\ As slauchtir hirschep thift and reiff \\ Distructioun of all polecey \\ and all manner of maist mischief, ${ }^{63}$
}

he was talking about the whole country. However, crime occurring in the Borders seemed to attract an extra level of opprobrium. The government's perception-of endemic violence in the Borders and of the stereotypically violent borderer-ignored 
the use of private and public violence to settle dispute in sixteenth century Scotland. This perception mattered: it influenced government policies in the Borders and has affected most subsequent analyses of the region.

Why had the Borders attracted this notoriety and extra level of governmental opprobrium? It is necessary to separate the types of crime in the Borders that were causing concern. Firstly, there was "ordinary" internal crime, similar to others parts of Scotland, as detailed above. Secondly, there was cross-border crime, necessarily specific to the Borders, which usually involved the theft, sometimes on a large scale, of livestock. It was this cross-border crime, however, rather than domestic crime, which fuelled the perception of the inherently wicked borderer and attracted the most governmental attention to the region. Such interest was generally prompted by a (usually temporary) change in Anglo-Scottish relations during which cross-border crime became less acceptable to the privy council, rather than a real increase in the incidence of such crime. ${ }^{64}$ Therefore the censorious preambles to privy council ordinances that resulted were often influenced by worries over cross-border crime and should not be confused with the internal crime in the Borders. In other words, our assessment of the Borders should not be tainted by the impression that crossborder crime contemporarily gave the region.

Governmental interest in the Borders was sporadic. Good cross-border relations seemed to stimulate such interest. During the regency of the Anglophile earl of Morton, from 1573 to 1578 , Morton conducted at least nine armed judicial raids into the region. ${ }^{65}$ Such raids were intended to make a lasting impression on the "thieves and disordered people" of the Borders. Following a raid to Jedburgh, in August 1573, Morton emphasized to Lord Burghley that he had "travailed these days past with our disordered people inhabiting the frontier that I hope good fruits shall follow thereon to the comfort of the good people of both the countries." Similarly, in 1586, against the background of negotiations over an Anglo-Scottish league and an English pension for James, a muster at Peebles was ordered to punish those who committed offences "against the subjects of [James's] dearest sister and cousin the Queen [Elizabeth to the] trouble and hazard of the good peace and amity standing between the two realms." 66

However, the periods when government seemed to ignore English complaints over cross-border crime should also be considered. It often seemed to the English that, at the very least, James's government turned a blind eye to disturbances in the region: it was said that he "doth wink thereat." Several English officials went further: in 1587 Lord Hunsdon, the English East March warden, considered that "such great outrages durst not be attempted by such men as hath done them, without the King's 
privity [knowledge].” Both of James's most powerful officials in the Middle March, Cessford and Buccleuch, were involved in cross-border raiding and violence. For instance, in 1596 it was claimed that Buccleuch "was principal" at the capture and murder of several Englishmen at Hexham in the English Middle March and others in the West March. He was accused further of "incursions and outrages" and enabling his tenants in Liddesdale, who were joined to him "by oathe and scripte" (and whom he was supposed to restrain), to raid into England. Similarly, Cessford was said to be protecting his kinsmen and allies from English accusations over "the very great loss [caused by] the last great rode of the Scots into England.” In 1597, perplexed by James's continued use of these officials, Sir Robert Bowes, Hunsdon's successor, despaired of James's reluctance to "bridle these wicked clans," doubting "whether it spring of too much facility, or too little sincerity": he concluded, "I consider their actions are done 'by him or for him'. In 1596 Lord Scrope, the English West March warden, railed against his bitter enemy, Buccleuch, that though Buccleuch was ready "to invade us [...] this man is thought fit by the King and Council to be still officer!" He observed the "greatest murderers are made the chief governors of the frontiers." As the Scottish courtier Maitland had written previously: "To se sa grit stouthe quha wald trowit/ onles sum grit man allowit." 67 Cross-border crime, which had probably been encouraged by the state, should not unfairly prejudice any assessment of crime within the region. Governments may say one thing in public but pursue a different course in reality; and it certainly seems discordant that James's government, which appeared to be using disorder privately as a diplomatic tool, chose to publicly castigate the borderers as "disorderit"! 68

Nothing suggests more the government's complicity than the rapidity of what happened when James appeared to alter his policy in the Borders. In 1597 there seemed to be a sea-change in his attitude to borderers such as Buccleuch and Cessford. Following Buccleuch's rescue in 1596 of Kinmont Willie, an ally of Buccleuch's, from Carlisle castle, there had been an escalation of English complaint against Scottish border officials. For a long time James held out against Elizabeth's demands for the surrender of these men to English ward. Scrope complained that James and the privy council "intend to extenuate and bear out Buccleuch's 'proud act." ${ }^{\prime} 9$ However, a number of pressures forced James to rethink his border policy. Firstly, Elizabeth withheld the payment of his pension, directly linking its resumption to the disciplining of Buccleuch. ${ }^{70}$ Then, in November 1596, the council reregistered a letter from Elizabeth of 1586 in which she had alluded to James's right to succeed her. James appears to have been becoming nervous about Elizabeth's continuing refusal to formally acknowledge his succession to the English throne. ${ }^{71}$ By the end 
of 1597, James's nerve seems to have weakened and he agreed to the surrender of Buccleuch to the English in October and that of Cessford in February 1598. Bowes reported that James, "straitened by her Majesty's last letters," had finally realized that Cessford "was not worth balancing against the Queen's merit." That May James received his delayed $£_{3000}$ sterling from Elizabeth..$^{72}$ After their release, Buccleuch and Cessford came into line with James's new policy: both were subsequently rewarded by him with confirmations of baronies and titles. ${ }^{73}$

From then on, James was to pursue a newly consistent policy in the Borders in which the maintenance of good relations with Elizabeth was paramount. Any subsequent cross-border transgression was viewed with alarm, while those that perpetrated it were to be treated with increasing severity. There were seven judicial raids into the Borders from 1597 to 1603 , mostly to the West March, where the Maxwell-Johnstone feud still burned brightly. In 1600, following the murder of his "beloved" West March warden, Sir John Carmichael, James ordered the trial of an Armstrong man who had been kept as a pledge for the good behaviour of his surname. The man was known as "a common and notorious thief," but if the court at Dumfries could find nothing against him, he was still to be executed for the involvement of his surname in Carmichael's murder. In 1601, James ordered that Roxburgh should try a Scottish minister for the murder of an Englishman. He was to put his head "upoun a publict place of the merche [...] to be a testimony to both the nations of our earnest care that friendship, love and amity may be entertained." That May, Elizabeth recognized his efforts, raising his pension to $£ 5,000$ sterling, and in 1602 it was reported that Elizabeth "does much commend the great care which the King does show to preserve the mutual peace." 74 James's measures in the Borders and the censure to which borderers were subjected to after 1597 should therefore be seen within the context of his concerns over the succession and the subsidy.

After 1603, with the crown of England firmly on his head, James was to maintain this new consistency in the Borders. Any disturbance in the Middle Shires, at the heart of his newly unified kingdoms, was to be seen as a direct threat to the success of that union. Anyone who appeared to threaten the union was viewed with particular opprobrium. Thus, in 1605 the new commissioners of the Middle Shires were ordered to "root out all malefactors for the present but [also] to continue a severe course of justice [...] for the perpetual preservation of these countries in peace."75 A memorandum of 1604, in James's own hand, made his intentions clear: "to extinguish as well the name, as [the] substance of the borders, [...] the difference between them and other parts of the kingdom. For [the] doing whereof it is 
necessary that quarrels amongst them be reconciled and all strangeness between the nations be quite removed." 76

The overriding priority was that the Borders should be the same as anywhere else in the new Great Britain. But there was a fundamental flaw in these plans in the form of the continuation of separate English and Scottish legal systems. Discussions between the Union commissioners stumbled over James's wishes for a standardization of laws within Britain. As Brian Levack notes of contemporary opinion, if "the union were to be an incorporating one, a union of laws appeared to be a necessity": yet, as he observes further, the "most formidable obstacle of all [...] [was] the substantial differences" between the two legal systems. These differences were never to be resolved. Sir Francis Bacon's suggestion for an Anglo-Scottish court to try cases from either side of the border under a practical mix of both countries' laws made no headway. ${ }^{77}$ But perversely the border-specific institutions set up in 1605 to achieve this similarity continued to differentiate the Borders. The commissioners were given wide-ranging jurisdiction over all the marches on their side of the border, which exceeded that of the previous wardens, who had been limited to their own individual marches. They were to be assisted by a paid and mounted border guard under the captainship of Sir William Cranstoun. The lack of such a guard had previously been blamed for the wardens' failure to maintain the effect of judicial raids into the region. ${ }^{78}$ For James the disappearance of the international nature of the border was so obvious that he clearly felt that any crime there would melt away as easily. However, continuing reports of crime spurred him, in December 1606, to complain that "we do not find so good success of your proceedings as we expected" and to announce the appointment of the earl of Dunbar as lieutenant over all the Middle Shires. ${ }^{79}$ Dunbar was to be the only man to have supra-border jurisdiction, and after his premature death in 1611 no commissioner ever achieved such status: the existence of separate commissions for each side of the border continued to demarcate the region from its counterpart and from the rest of the multiple kingdoms.

Exemplary severity was the hallmark of this newly consistent pacification. Sentencing guidelines were made more extreme and indicated the government's priorities in the region: thus the importance given to the suppression of cross-border theft could be seen in the ruling that theft of goods over twelve pence in value "shall be punished by death" and, significantly, "all accessories to such felonies, viz outputting and resetting, shall likewise suffer death for the same." This compared with the lenient 20 -day sentence for harming with a weapon. ${ }^{80}$ There was evidence that Dunbar, Cranstoun, and the commissioners consciously used their jurisdiction somewhat 
harshly. The English commissioners observed of a court held at Hawick in August 1605 that their Scottish counterparts "made no bones to kill such fugitives or felons as made resistance." In January 1606 the Scottish commissioners reported of their work at Peebles that they had convicted six offenders whom "we have exemplarily punished with life," while in May they executed a further 32 men by "water and gallows" at courts in Hawick, Peebles, Jedburgh, and Dumfries. ${ }^{81}$ Dunbar's work was noted to have "given more occasion of fear and terror to the evil disposed of those parts, and his very name there has suppressed more disorders than all the Commissioners could do." 82 The numerous indemnities granted to Dunbar and Cranstoun suggest the severity of their methods: one such exonerated Cranstoun's actions when he was forced "to make a quick dispatch of a great number of [offenders] without any conviction or doom given against them by an assize, and sometimes to besiege them in houses and strengths and to raise fire against them." ${ }_{3}$

The contempt with which the privy council viewed some borderers was evident in its recommendations in 1605 . Observing that "some order be taken with the idle youths" of the Borders and calling the area a "seminary of theft," the council suggested that "no border man of any broken name shall part his rowmes or steadings amongst his children but all to go to the eldest: And the rest who have nothing to live upon sufficiently to be transported whither his Majesty and the council thinks fit." 84 People who were seen as an impediment to the new way of life in the Middle Shires were simply to be removed. The council thought that "the change of air will make in them an exchange of their manners," while the Bishop of Carlisle entreated that the Annandale and Liddesdale should be "purged" of the Armstrongs, Nixons, and others since James was "so well understanding of the wickedness of the inhabitants." He suggested that these men should be transported in the same way that it was planned to transport the Grahams from Cumberland. ${ }^{85}$ The notion of transportation per se indicates the dismissive way in which government viewed borderers, and the treatment of the Grahams recalled the targeting of the "wicked Clan Gregor" from 1600. ${ }^{86}$ Initial plans to transport the male Grahams to join the English army at Flushing in the Low Countries proved shortlived, as they filtered back to the Borders. Subsequently, from 1606 there was a more successful transplantation of whole families of troublesome borderers to Ulster. This however should also be seen within the context of a colonization programme, from 1609, which encouraged the settlement of Scottish lairds on estates in Ulster, in order to undermine Irish resistance to English rule. ${ }^{87}$ Further recommendations by James in England to transport borderers to Virginia in 1618 were resisted by the Scottish privy council. Such measures say much about how borderers were perceived by 
central government and much has been made of such moves, though they affected only a small minority in the Borders at this time. ${ }^{88}$

As much as disorder in the Middle Shires was seen to threaten union, it also presented a challenge to James's authority, an authority for which he claimed divine origins. Thus, any disorder was described as "wicked" or "evil," and the work of the godless, since it contradicted his divine authority. Disorderliness was equated with godlessness and barbarism. In the sixteenth century, Maitland had described the thieves of Liddesdale as guided by "ye meikle devil" and that they all had "the devil received," while in the seventeenth century the privy council denounced borderers for perpetuating the "unnatural and barbarous custom" of feuding. A lieutenancy granted to Lord Home in July 1603 called for him to reduce the borderers to a "godly, peacable and quiet form of living," while the new commissioners of 1605 were told to deal with those leading a "godless, lawless and disordered course of life." ${ }^{89}$ Lord Sheffield noted that "it were fit the Borders [...] should be lightened by the preaching of the Word, being the only way to bring them to civility who are now so barbarous." 90 In 1609, in a letter to his loyal ecclesiastical enforcer, John Spottiswoode, archbishop of Glasgow, James attributed "the bypast barbarity and incivility" in the Middle Shires to "the inhabitants in most part[s] thereof being void of all true fear of God and religion." ${ }^{11}$ Therefore, any rehabilitation of the borderers would have to encompass changes in more than the temporal influences in their lives.

As a result, in 1608 the General Assembly of the Kirk of Scotland, prompted by James, appointed Spottiswoode to combine with the lieutenant of the Middle Shires, the formidable earl of Dunbar, in a plantation of those border kirks presently destitute of ministers, particularly in the dales of the Annan, Esk, and Ewe. James added his approval the following March, "to the advancement of God's glory," and ordered Spottiswoode to rebuild decayed kirks and to sack incompetent ministers. Wayne Pearce notes that Spottiswoode's "exertions in this region must be interpreted as an integral part of this wider campaign to 'civilise' the Borders." 92 But it should also be noted that Spottiswoode's work in the border dales was also part of a more general program by the kirk to improve ecclesiastical standards throughout Scotland. And Spottiswoode himself was James's main agent in his attempts to control the activities of the more rebellious members of the General Assembly and the presbyteries. ${ }^{93}$ The link between the work of secular and religious authorities was underlined, in 1610 , by the appointment of Spottiswoode as a JP for the shires within his diocese of Glasgow, reinforcing his ecclesiastical jurisdiction over the area. ${ }^{94}$

The creation of commissions of the peace in the Borders' shires, of which Spottiswoode's was one, brings us full circle back to James's wider development of 
judicial systems throughout Scotland. The appointment of JPs in the Borders was as much a broadening of crown authority there as it was anywhere else in Scotland. Julian Goodare notes a "dramatic expansion" in the numbers of local administrators and the extension of the "authority of the state further down the social scale."95 Traditionally, local jurisdiction (when it was not restricted by private jurisdictions) lay in the hands of the sheriff. The hereditary nature of this office had come to be seen by James as most detrimental to the efficacy and impartiality of local judicial processes. Thus the appointment of JPs throughout Scotland in 1610 was one way in which the crown could attempt to increase its control over judicial processes nationally by creating an alternative body, appointment to which the crown controlled, to balance the sheriff's authority. James had envisaged that Scottish JPs would replicate those in England: however, the function of Scottish JPs seemed to be more concerned with social and economic administration, such as the administration of poor relief, rather than the administration of justice. As a result, they did not seem to challenge the authority of the sheriffs. ${ }^{96}$ Moreover, most sheriffs received a commission of the peace. Thus, local lairds benefited from the powers associated with their new commissions while the government was able to use these lairds' networks of kinship and alliance to effect its policies in the localities.

The commission called for "godly, wise and virtuous gentlemen," again linking godliness with the execution of justice and the imposition of order (although it would have been difficult to apply these criteria to several of the Borders's JPs such as Buccleuch, Cessford, and Walter Scott of Harden.) The fact that all the JPs nominated were familiar names from lairdly families, who had subscribed general bands back through several generations, illustrates conclusively how James had been able formally to draw such men into the evolving structure of his government. He had thus retained not only their service in their localities but their authority over their kindreds. And this was the same for the Borders as it was for the Lothians, or Fife, or Stirling.

James also attempted to regain control of the appointment of sheriffs: in Basilicon Doron he had observed "the greatest hindrance to the execution of our Laws in this country, are these heritable sheriffdoms and regalities, which being in the hands of the great men, do wrack the whole country." As we have seen, he had already tried to hold the sheriffs to account for their efficiency in his last years in Edinburgh. But after he went south, negotiations were conducted with several hereditary sheriffs for the surrender of their offices. By 1625 this had led to the surrender of eight sheriffships. ${ }^{97}$ Protracted discussions were held with one of the Borders' incumbents, Sir John Murray of Philiphaugh, sheriff of Selkirkshire. In 
1615 Sir Gideon Murray of Elibank, the deputy treasurer, wrote to James that he had persuaded his cousin, Philiphaugh, to accept a life-rent pension of $£ 500$ a year for the surrender of his office. He noted that this was considerably less than the $£ 3,000$ sterling granted to Lord Grey for his office and that "the case of his price might be an argument to bring others who might be hereafter dealt with for renunciation of the like offices, to be content with moderate satisfaction." Philiphaugh finally surrendered his office in 1619 and it became an annual appointment. Philiphaugh did not, however, lose his authority in the region, acting as a Middle Shires commissioner, a JP, and again as the sheriff in 1623 and $1625 . .^{8}$

The combination of the crown encouraging the resolution of disputes within central courts in Edinburgh, and its attempts to regain control over the appointment of judicial officials, effectively led to an increase in the state's control of judicial powers and also in the structure of government itself. Michael Wasser's study of violent cases coming before the privy council and high court from 1603 to 1638 notes a decline in the overall number of cases, which he links to this increase in the power of the state. However, this was only part of a process that was not completed in James's lifetime or even that of his son, Charles. As Wasser usefully observes, the cases before the central courts still tended to be private actions, rather than state prosecutions, though a change had begun which was to prove inexorable. It is important to remember, as Julian Goodare emphasizes too, that the evolution of the state was an on-going process. ${ }^{99}$

However, as previously noted, any definition of the state should encompass the interactions of its individuals. For seventeenth century England, Michael Braddick has identified a process of state formation that helpfully suggests the importance of the dynamic in the evolution of the framework of state, rather than merely the institutions created. ${ }^{100}$ In other words, what is significant is how government worked through the co-operation of the crown officials amongst the landed elite, and the way in which these agents could effect any central governmental directives in their own localities. Keith Brown notes the co-operation of the nobility in suppressing feud; Michael Braddick notes the co-operation of the landed elite with the state in England; and my own study of the Borders has shown how the leaders of the kindreds co-operated with the crown in the suppression of feuding and in the pacification of the Borders. They became the official agents of the crown, while the offices themselves rewarded their co-operation. ${ }^{101}$

It is difficult to quantify the effect of the increasing power of state on crime: however, both Brown and Wasser conclude that the incidence of violent crime was decreasing by the 1620 . Figures for the Borders suggest a similar decline. Certainly, 
the record of crime in the Scottish Borders, having been prominent in discussions between James and his English privy council, had by 1620 almost disappeared as a topic. In 1621, the English privy council observed that the Borders were "now brought to a peaceable estate." It recommended that the commissions of the Middle Shires should be abolished and that "a more ready and less chargeful mode of governing" should be devised. Similarly, James, noting that "our kingdom is reduced to such quietness," directed that the Scottish privy council should disband the border guard. ${ }^{101}$

However, it was not long before complaints surfaced: in February 1622, the Middle Shires commissioners complained to the privy council of an increase in crime in Annandale, Eskdale, Nithsdale, and Ewesdale, which they attributed to the discharge of the guard. In response, a triumvirate was appointed of three borderers of "power and friendship" in the region. These were Francis Scott, earl of Buccleuch, Robert Maxwell, the new earl of Nithsdale, and John Murray, the future earl of Annandale, all of whom held extensive lands in the region and could use members of their kindreds as their paid armed deputies. This triumvirate held judicial powers superior to those of the original Middle Shires commission, but the original commission, dating back to 1605 , continued to exist: indeed, it was expanded by four men in 1623 from the West March, which was deemed to be the area of most concern. ${ }^{103}$ Here, the Maxwell-Johnstone feud still continued: though the principals had, in theory, settled their differences, it would take longer for those of their adherents to be resolved. An exemption to some Johnstones from the jurisdiction of Nithsdale and his deputies was granted because there was "great reason [...] to suspect some trouble and inconvenience to follow [...] [since] the heartburning between their friends and followers is not yet fully extinguished."104

James had certainly achieved some sort of "order" in the Borders. But was this the order that he had imagined would exemplify and underpin a full political Union? The continuing existence of the Scottish Middle Shires and triumvirate commissions suggests that there was still a need for a border-specific institution which demarcated the region from the rest of Scotland, let alone the multiple kingdoms. There was also recurring resistance, from 1604 onwards, to the principle of remanding offenders for trial in the country of their offence: remanding was seen, by James, as a crucial deterrent to those seeking refuges on the other side of the border. ${ }^{105}$ Though by 1612 legislation was finally passed on this issue by both countries' parliaments, remanding was still a cause for concern in 1617; in 1623 Buccleuch had difficulty in extraditing a fugitive from Northumberland. ${ }^{106}$ Part of the problem lay in the continuation of separate legal systems in the two countries: James's attempts to standardize the 
laws had stalled. As Sir Edward Coke, the English attorney general, observed in 1606, "it will not appear which will be the middle shires, for a jury of England and Scotland cannot yet join. And for many respects I think that such a proviso would be very offensive." 107

And what of the harmonious cross-border relations that events in the Middle Shires were meant to illustrate? Initial relations between the Middle Shires commissioners of each country were cordial. By December 1606, however, they had already begun to deteriorate. The English commissioners were complaining about the severity of the Scottish commissioners, while the Scottish remonstrated with the English, urging them to search the farms on their side more carefully: "for we are informed that the fugitives have their maintenance there, dreading our side more than their own." A similar complaint about English laxity was made by another Scottish commissioner in $1621 .{ }^{108}$ In 1622 a private dispute between Home of Wedderburn and the English Lord Walden, over the fishing rights on the Tweed, led to an outbreak of violence between their retainers. James and the privy council ordered an arbitration of the dispute several times, but it was unresolved on James's death in 1625 . Wedderburn's request, that "in everything the commission [for the arbitration] be conceived in equal terms for both nations, and that what ever privileges the English have, we may not be deprived the like," typified the mutually hostile and self-defensive relations between the two countries on their border. ${ }^{109}$ If James failed to secure full political Union in his lifetime-and it is significant that legal, ecclesiastical and parliamentary systems remained both separate and distinctive-it was, perhaps, too much to expect the effects of 300 years of hostility to be overcome, overnight, in the heartlands of that antagonism.

Despite these qualifications, however, a new type of order did prevail in the Borders. Those borderer lairds who had occasioned such frequent English complaint were now paid-up and honoured participants in the highest levels of government. In the Borders, the members of the landed elite were in the process of transforming their private authority over their own kindreds and allies into an official authority over the whole locality as agents of an expanding framework of government. The figures for violent crime were declining. But the Borders were not singular in these changes: the region was affected by a broader process of increasing crown harnessing of legal processes and the concentration of authority throughout Scotland within the hands of new government agents. A new order was being instituted throughout Scotland. And this order would not tolerate the past practices of the defenders of the kingdom's border: those activities now challenged the authority of the crown and its moves towards full Union. James, at his glittering new court in London, no longer 
needed disorder in the Borders to keep England on guard: the bold and patriotic "free-booter [that] may be many a man's relief", of Scott of Satchell's eulogy to his forebears, became "but a thief." 110

\section{Notes}

1. Speech by James to Houses of Parliament, Whitehall, 31 March 1607, in King James vi and I: Political Writings, ed. J.P. Sommerville (Cambridge: Cambridge University Press, 1994) p. 169.

2. James Vi speech to the Upper House of the English Parliament, 19 March 1604, in Political Writings, p. 135.

3. The Register of the Privy Council of Scotland, first series, ed. J.H. Burton and D. Masson, 14 vols. (Edinburgh: HM General Register House, 1887-98), vol. 6, pp. 560-1. (Henceforth, RPC.)

4. Political Writings, p. 25 .

5. This paper does not seek to provide a full account of the pacification which is available elsewhere: for the Scottish Borders, see Michael B. Wasser, The Pacification of the Scottish Borders, 1598-1612 (master's thesis, McGill University, 1986); Maurice Lee, Government by Pen: Scotland under James vi and I (Urbana: University of Illinois Press, 1980); and Anna Groundwater, The Middle March of the Scottish Borders, 1573 to 1625 (Ph.D. diss., University of Edinburgh, 2007). For the English Borders, see Diana Newton, North-East England, 1569-1625: Governance, Culture and Identity (Woodbridge: Boydell Press, 2006); S. J. Watts, From Border to Middle Shire: Northumberland 1586-1625 (Leicester: Leicester University Press,1975); and R. T. Spence, "The Pacification of the Cumberland Borders, 1593-1628," Northern History (1977), pp. 59-160. For a treatment of both sides of the border, see Jared R. M. Sizer, Law and Disorder in the 'Middle Shires' of Great Britain, 1603-1625 (Ph.D. diss., Cambridge University, 2001). For the Scottish Borders before 1603, Ian Rae's book remains the definitive work on the administration of the frontier: The Administration of the Scottish Frontier, 1513-1603 (Edinburgh: Edinburgh University Press, 1966). Also, for the period before 1603, see Maureen Meikle's exhaustive survey of the lairds and gentry of a cross-border area she terms the Eastern Borders, which encompasses both the English and Scottish East Marches and part of the Scottish Middle March: A British Frontier? Lairds and Gentlemen in the Eastern Borders, 1540-1603 (East Linton: Tuckwell Press, 2004).

6. Julian Goodare and Michael Lynch, "The State and its Borderlands," in The reign of James VI, J. Goodare and M. Lynch, ed. (East Linton: Tuckwell Press, 2000), pp. 186-207.

7. Susan Doran, "Loving and Affectionate Cousins? The relationship between Elizabeth I and James VI of Scotland, 1586-1603," in Tudor England and its neighbours, S. Doran and G. Richardson, ed. (Houndmills: Palgrave Macmillan, 2005), pp. 203-33. 
8. Julian Goodare, “James vi's English Subsidy," in The reign of James vi, pp. 110-25; Groundwater, pp. 228-30.

9. For details of these offices, see below.

10. Bruce Galloway usefully noted that any attempt to look at James's policies towards the Borders should be viewed within the context not only of union but also of his ideas of kingship: "it is difficult to separate action taken to advance the Union from the simple continuation of longstanding policy" and that the pacification "reflected James's emphasis on the extension of centralised authority throughout his dominions." See B. Galloway, The Union of England and Scotland, 1603-1608 (Edinburgh: John Donald,1986), pp. 65-68, 84-86, 120-27; Diana Newton also links increased attention to the Borders in 1605 to James's invigoration of the "government of the realm," in The Making of the Jacobean Regime: James vi and I and the Government of England, 1603-1605 (London: RHS, 2005).

11. The most comprehensive evaluation of the evolution of the state in Scotland in this period is by Julian Goodare. See his State and Society in early modern Scotland (Oxford: Oxford University Press, 1999) and, The Government of Scotland (Oxford: Oxford University Press, 2004). Keith Brown's ground-breaking work on feud, and James's involvement in its suppression, concludes that in this period "violence moved closer to being a state monopoly" in which James largely achieved "the limitation of the legitimate right to employ violence to the crown" and its agents. Brown delicately links this process to a subsequent and "very gradual accumulation of state power" in the first 30 years of the seventeenth century. See K. M. Brown, Bloodfeud in Scotland, 1573-1625 (Edinburgh: John Donald, 1986), pp. 259, 269-70.

12. Neither was achievable, as Goodare notes, "if only because history never comes to an end." See Goodare, State and Society, p. 100.

13. The Borders included, from east to west, the shires of Berwick, Roxburgh, Selkirk, Peebles, and Dumfries. The records for the sheriff of Roxburghshire's court, held at Jedburgh, show that it was sitting on an almost weekly basis throughout this period. National Archives of Scotland (NAS) sc62/3-7.

14. Rae, chapter two.

15. Goodare, State and Society, p. 73.

16. The Acts of the Parliaments of Scotland, 1424-1707 (London: 1816), vol. 3, pp. 461-67. (Henceforth, APs.)

17. James VI, Basilicon Doron, in Political Writings, p. 43.

18. RPC, vol. 4, p. 552; RPC, vol. 5, p. 130-31.

19. RPC, vol. 5 , p. 755 .

20. RPC, vol. 6, pp. 233-34.

21. RPC, vol. 5, pp. 90-91, 274-75, 321-22, 437-38, 463, 497; APS, vol. 4, pp. 164, 228.

22. Brown, especially ch. 2. See the following by J. M. Wormald: Lords and Men in Scotland: Bonds of Manrent, 1442-1603 (Edinburgh: John Donald, 1985); "Bloodfeud, Kindred and Government in Modern Scotland," in Past and Present 87 (1980), pp. 54-97, 
especially pp. 66-71; Court, Kirk and Community: Scotland 1470-1625 (London: Edward Arnold, 1981), pp. 36-37.

23. RPC, vol. 5, pp. 248-49.

24. Brown, p. 259.

25. David Moysie, Memoirs of the affairs of Scotland, 1577 to 1603 (Edinburgh: Bannatyne Club, 1830), p. 63; APS, vol. 3, p. 458.

26. RPC, vol. 5, pp. 248-49, 261, 262-63, 273, 303-04, 387, 392-93, 403, 452-53, 462, 475.

27. RPC, vol. 5, p. 248-49.

28. RPC, vol. 5, pp. 261, 262-63, 273, 280,303-04.

29. APs, vol. 4, pp. 158-59, 233-35.

30. Rae also ascribed to this view: however, it is less tenable following the work done by Wormald and Brown on feuding, and the reassessment of the strengths of Scottish government by Goodare et al. See Rae, pp. 9-10, 123-26.

31. The Border papers: Calendar of Letters and Papers relating to the Affairs of the Borders of England and Scotland preserved in her Majesty's Public Record Office, London, ed. J. Bain, 2 vols. (Edinburgh: HM General Register House, 1894-96), vol. 2, no. 323. (Henceforth, Свр.) A similar complaint was made by the English privy council in 1602: Calendar of the State Papers relating to Scotland and Mary, Queen of Scots, 1547-1603, ed. J. Bain et al, 13 vols. (Edinburgh: HM General Register House, 1898-1969), vol. 13, pt.2, no. 828. (Henceforth, CSP Scot.)

32. СвP, vol. 2, no. 432; Maureen M. Meikle, "A godly rogue: the career of Sir John Forster, an Elizabethan Border warden," Northern History 28 (1992), pp. 126-63.

33. NAs Records of the Privy Council of Scotland, 1545-1707, PC10/3/iv/33

34. RPC, vol. 6, p. 46.

35. RPC, vol. 12, pp. 673-75.

36. NAS Duke of Buccleuch Muntments GD224/1059/17; CSP Scot, vol. 12, nos. 197, 224; Groundwater, pp. 63-65.

37. NAS Lothian Papers GD40/2/11/56; National Register of Archives for Scotland, Roxburgh Papers NRAs1100/637. Meikle details the feuds between the Kers, in A British Frontier?, pp. 37, 6o-62, 69, 71, 75, 77, 80-81.

38. GD40/9/3; 40/2/12/50; Groundwater, pp. 66-67.

39. Brown, pp. 6-7; Groundwater, chapter four.

40. RPC, vol. 5, pp. 248-49; , vol. 7, pp. 545-697; vol. 8, pp. 629-733.

41. Brown, pp. 6-7, 277.

42. Brown, pp. 258, 276.

43. Brown, pp. 234-35, 258-59, 268-70.

44. Maureen Meikle shows how blurred the division was between the nobility and the "greater lairds," both exercising similar levels of authority in the localities: see "The invisible divide: the greater lairds and the nobility of Jacobean Scotland," Scottish Historical Review 71 (1992), pp. 70-87.

45. NAS Scott of Harden Papers, GD157/162. 
46. Sir William Fraser, ed., The Scotts of Buccleuch, 2 vols. (Edinburgh: Edinburgh University Press, 1878), vol. 2, no. 202; GD224/906/68/4.

47. Julian Goodare, “The admission of lairds to the Scottish parliament,"English Historical Review 116,5 (2001), pp. 1103-33.

48. Bothwell was Buccleuch's stepfather and a cousin of James vi. Between 1592 and 1594 he mounted a series of raids against the king before he escaped into exile, dying in Denmark in 1612. R. G. Macpherson, Francis Stewart, fifth earl of Bothwell, c.1562-1612: lordship and politics in Jacobean Scotland (Ph.D. dissertation, University of Edinburgh, 1998).

49. Fraser, ed., pp. 174-75, 178; vol. 2, no. 211; RPC, vol. 5, p. 179.

50. CBP, vol. 2, no. 232.

51. There were at least nine such bonds signed by Liddesdale men to Buccleuch in 1599. GD224/906/5; Fraser, ed., vol. 2, no. 216.

52. GD224/918/12;224/917/34,35; RPC, vol. 9, pp. 75-76, 138-39; vol. 10, p. 162.

53. For further discussion of this, see below.

54. GD224/889/1; Fraser, ed., vol. 1, pp. 230-32.

55. “The Diary of Robert Birrel," in Fragments of Scottish History. ed. Sir John Graham Dalyell (Edinburgh: Archibald Constable, 1798), p. 41.

56. Sir Richard Maitland of Lethington, "Aganis the Theivis of Liddisdaill," in W.A. Craigie, ed., The Maitland Folio Manuscript (Scottish Text Society 1919), vol. 1, pp. 301-03.

57. The records of the sheriff court of Roxburghshire are dominated by cases of nonpayment and inheritance disputes, while cases relating to feuding predominate in those of the court of session. SC62/3-7; Cs7/111-383 (1587-1625). Pitcairn's selection of cases appearing before the high court of justiciary between 1600 and 1609 are almost all cases of feud-related killing except for a couple relating to persistent smallscale livestock raiders. See R. Pitcairn, Ancient Criminal Trials in Scotland (Edinburgh: Bannatyne Club, 1833), vol. 2, pt. 2.

58. Rae, pp. 3-4, 9; D. L. W. Tough, The Last Years of a Frontier: A history of the Borders during the reign of Elizabeth I (Oxford: Oxford University Press, 1928), pp. 34-6, 183.

59. RPC, vols. 2-6; Groundwater, p. 169 and App. G.

60. Michael Wasser, Violence and the Central Criminal Courts in Scotland, 1603-1638 (Ph.D. dissertation: Columbia University, 1995), pp. 57-58.

61. Wasser, "Violence," pp. 13, 56, 58, 62; Dixon provides figures for cross-border raiding derived from reports in the Calendar of Border Papers vols. 1, 2. Philip Dixon, Fortified Houses on the Anglo-Scottish Border (Ph.D. dissertation: Oxford University, 1976), p. 74 .

62. Wasser, "Violence," p. 21.

63. Sir Richard Maitland, "Lament for the Disorderis of the Cuntrie," in Maitland Folio Manuscript, vol. 1, pp. 317-20.

64. Philip Dixon's survey of cross-border raiding concludes that large scale raids were probably diminishing through the second half of the sixteenth century and that the 
apparent increase in overall raiding was probably more of a reflection of increased recording rather than increased incidence. See Dixon, pp. 74-76.

65. Rae, App. 6; George R. Hewitt, Scotland under Morton, 1572-1580 (Edinburgh: John Donald, 1982), chapters $7 \& 9$.

66. CSP Scot, vol. 4, no. 723; RPC, vol. 4, pp. 84-85, 92; Groundwater, pp. 188-89, 213-14.

67. СвP, vol. 1, nos. 499, 560; vol. 2, nos. 231, 232, 237, 253, 336, 603; CsP Scot, vol. 13, pt. 1, no. 3; Maitland, "Aganis the Thevis of Liddesdaill," p. 302.

68. Groundwater, pp. 181-83.

69. СвP, vol. 2 , nos. $473,475,476$.

70. СвP, vol. 2, no. 284; Letters of King James vi and I, ed. G. P. V. Akrigg (Berkeley: University of California Press, 1984), pp. 150-51, 152-53; Goodare, "James VI’s English subsidy," pp. 110, 116.

71. RPC, vol. 5, pp. 324-25; S. Doran, pp. 218-221.

72. СBP, vol. 2, no. 909.

73. For instance, James confirmed the grant to Cessford of an annual pension from the abbacy of Kelso in 1600 in recognition of "his gude honorabill and thankfull service." NRAS1100/728.

74. RPC, vol. 6, pp. 117-18, 127-28; HMC $14^{\text {th }}$ Report, The Manuscripts of the Duke of Roxburgh (London: HMSO, 1894) vol. 3, no. 74; CSP Scot, vol. 13, pt. 11, nos. 659, 828.

75. The Scottish Middle Shires commissioners remained remarkably similar from 1605 to at least 1619, despite the issuing of new commissions in 1607, 1611, 1613 and 1617 - and most of them were appointed to the expanded commission in 1618. RPC, vol. 7, pp. 701-04, 707-09; vol. 8, pp. 15-16; vol. 9, pp. 194-96; vol. 10, p. 164; vol. 11, pp. 11-14.

76. HMC 9th Report, Calendar of the Manuscripts of the Most Hon. The Marquess of Salisbury, 24 vols. (London: HMSO, 1883-1976), vol. 16, pp. 405.

77. Brian P. Levack, The Formation of the British State: England, Scotland and the Union, 1603-1707 (Oxford: Clarendon, 1987), pp. 69, 75, 91. See also Bruce R. Galloway, The Union of England and Scotland, 1603-8 (Edinburgh: John Donald, 1986), pp. 67-68.

78. RPC, vol. 7, pp. 701-04.

79. HMC 1oth Report, App.iv, The Manuscripts of Lord Muncaster (London: HMSO, 1885), pp. 266-67.

8o. RPC, vol. 7, pp. 707-09.

81. HMC Muncaster, p. 236; RPC, vol. 7, pp. 714-17, 717-20.

82. HMC Salisbury, vol. 18, pp. 368-71.

83. RPC, vol. 8, p. 279.

84. $\mathrm{PC} 10 / 7 / 45,46$.

85. RPC, vol. 7, pp. 701-04; HMC Salisbury, vol. 18, pp. 293-95.

86. RPC, vol. 5, p. 41; vol. 6, p. 72, 558n. In April 1603 a statute ordered that the name of MacGregor "should be altogether abolished." Aps, vol. 4, p. 550.

87. HMC Muncaster, pp. 257, 259-61; HMC Salisbury, vol. 18, pp. 214-16, 224-25, 284-86, 302; vol. 19, p. 127; RPC, vol. 8, pp. 792-94; M. Perceval-Maxwell, Scottish Migration 
to Ulster in the Reign of James I (London: RKP, 1999), pp. 22-23, 26, 97-100; also G. F. S. Elliot, The Border Elliots and the Family of Minto (Edinburgh: D. Douglas, 1897), pp. 177,199 .

88. In 1618 James compared the transportation measure to that taken against the clan Gregor. RPC, vol. 11, pp. 289, 313-14, 353-54.

89. Maitland, "Aganis the theivis of Liddisdaill," pp. 301-3; RPC, vol. 7, pp. 701-04, 706-07.

90. HMC Salisbury, vol. 17, p. 125.

91. RPC, vol. 8, pp. 266-67.

92. The Booke of the Universal Kirk of Scotland, 3 vols. (Edinburgh: Church of Scotland, 1860), vol. 3, pp. 1061-62; R PC, vol. 8, pp. 266-67; A. S. Wayne Pearce, John Spottiswoode, Jacobean Archbishop and Statesman (Ph.D. dissertation: University of Stirling, 1998), pp. 95-97, 170.

93. A comprehensive account of the resistance to James's measures within the kirk is provided by Alan MacDonald, in The Jacobean Kirk, 1567-1625: Sovereignty, Polity and Liturgy (Aldershot: Ashgate, 1998).

94. RPC, vol. 9, pp. 75-76.

95. Goodare, Government of Scotland, p. 203.

96. APS, vol. 4, p. 434; RPC, vol. 9, p. 75-76; Goodare, Government of Scotland, pp. 203-06.

97. Three of the eight surrendered were from the Borders: Dumfries, Berwick, and Selkirk. See Political Writings, p. 29; RPC, $2^{\text {nd }}$ series, vol. 1, p. 659; Goodare, Government of Scotland, pp. 187-90.

98. National Library of Scotland, Denmilne Adv Papers MS 33.1.1 vol.6 no.22; RPC, vol. 11, pp. 586-87; vol. 8, p. 333 .

99. Wasser, "Violence," pp. 1, 57-58, 293-301; Goodare, State and Society, pp. 100-01.

100. Michael J. Braddick, State Formation in Early Modern England, c.1550-170o (Cambridge: Cambridge University Press, 2000), p. 1.

101. Brown, pp. 268-69;Braddick, pp. 338,340; Groundwater, ch. 4.

102. Calendar of State Papers: Domestic Series, of the reign of James I, ed. M. A. E. Green (London: Longman, 1857); CSP Dom.1619-1623, p. 331; RPC, vol. 12, pp. 582-84.

103. RPC, vol. 12, pp. 650, 670-79, 775-79; vol. 13, pp. 155-57.

104. RPC, vol. 12, pp. 673-75; vol. 13, pp. 261-62.

105. Watts, p. 142, 148, 151, 155 HMC Salisbury, vol.17, p.151; Journals of the House of Commons (London: HMSO, 1803) vol. 1, pp. 375, 1045-49.

106. APS, vol. 4, p. 470; RPC, vol. 11, p. 290; CSP Dom.1623-1626, pp. 38, 82.

107. HMC Salisbury, vol. 18, pp. 186-87.

108. HMC Muncaster, pp. 235-36, 242; RPC, vol. 11, pp. 108-09.

109. RPC, vol. 12, p. 746 ; vol. 13 , pp. $178-79,703-5,722$; $2^{\text {nd }}$ series, vol 1, pp. $415-16$; HMC Colonel David Milne Home, p. 90.

110. Walter Scott of Satchells, Metrical History of the Honourable Families of the Name of Scott and Elliot (1688; Edinburgh: reprinted 1892), p. 9. 